10. Попиченко С. С. Про деякі аспекти забезпечення едукаційного середовища для розвитку особистості студента : посібник для вчителів і студентів / С. С. Попиченко, Н. В. Рогальська. - Умань : РВЦ «Софія», 2007. - С. 9-15.

11. Попова О. П. Розвиток творчого потенціалу майбутнього інженера в процесі професійної підготовки у вищому технічному навчальному закладі : автореф. дис. на здобуття наук. ступеня канд. пед. наук : спец. 13.00.04 / О. П. Попова. - Запоріжжя, 2006. $20 \mathrm{c}$.

УДК 37.091.12:510.2]:008 - 047.22

DOI: 10.37026/2520-6427-2020-101-1-90-93
12. Фещук Ю. В. Олімпіада з комп’ютерної графіки як засіб активізації пізнавальної діяльності студентів / Ю. В. Фещук // Трудова підготовка в закладах освіти. - 2011. - №7/8. - С. 47-49.

13. Чемоданова Т. В. Олимпиады и конкурсы по компьютерной графике как метод интенсификации процессов инженерно-геометрического мышления студентов технического вуза / Т. В. Чемоданова // Педагогическая информатика. - 2004. - № 4. - С. 74-78.

Дата надходження до редакиіï: 20.01.2020 р.

\section{ОЛеНа МАРЧЕНКО,}

кандидат педагогічних наук,

дочент кафедри природничо-математичної освіти

Рівненського ОІППО

\title{
РЕГІОНАЛЬНИЙ НАУКОВО-МЕТОДИЧНИЙ ПРОСКТ «КУЛЬТУРНІ КОДИ МАТЕМАТИКИ» ЯК ІНСТРУМЕНТ РОЗВИТКУ ПОЛІКУЛЬТУРНОЇ КОМПЕТЕНТНОСТІ ПЕДАГОГІВ
}

У статті аналізуються результати першого етапу впровадження регіонального науково-методичного проєкта «Культурні коди математики», спрямованого на формування й подальший розвиток полікультурноі компетентності вчителів математики. Висвітлюються його системні зв 'язки із провідними положеннями проєкта «Майбутнє освіти та вмінь. Освіта 2030» Організачії економічного співробітництва та розвитку, а також перспективні шляхи реалізації суспільного запиту на агентність та інноваиії в освіті.

Ключові слова: полікультурна компетентність, професійні компетентності педагога, агентність, міжкультурний діалог у проиесі вивчення математики, культурні ияінності в освіті.

В статье анализируются результаты первого этапа осуществления регионального научно-методического проекта «Культурные коды математики», направленного на формирование и дальнейшее развитие поликультурной компетентности учителей математики. Освешаются его системные связи с основными положениями проекта «Будущее образования и навыков. Образование 2030» Организации экономического сотрудничества и развития, а также перспективные пути реализачии общественного запроса на агентность и инновачии в образовании.
Ключевые слова: поликультурная компетентность, профессиональные компетентности педагога, агентность, межкультурный диалог в прочессе изучения математики, культурные ценности в образовании.

The results of the first stage of implementation of the regional scientific and methodological project «The Cultural Codes of Mathematics» are analyzed in the article. The project is aimed at forming and further development of multicultural competence of mathematics teachers. It revealed the systematical links with basic concepts of Organisation for Economic Co-operation and Development (OECD) project «THE FUTURE OF EDUCATION AND SKILLS. Education 2030».

The article explored perspective directions of public inquiry into agency and innovations in education. It is just the problems of educational agency and the formation in its context of multicultural competence of the subjects of the educational process that the project «The Cultural Codes of Mathematics» is devoted.

The Ukrainian mathematics curriculum explanatory note for 5-9 grades explains that mathematics teaching should make some contribution to the formation of key competences, including information and understanding the cases of manifestation of mathematical laws in the field of culture. According to this the project 
"The Cultural Codes of Mathematics» is aimed at the formation of student's awareness of the interconnection of mathematics and culture on the examples of architecture, painting, music and other manifestations of culture.

The results of the questionnaire of mathematics teachers of Rivne region are presented in the article. The questions of the questionnaire were devoted to clarify teacher's understanding what the multicultural competence means and how teachers can shape it into the process of teaching mathematics.

Key words: multicultural competence, professional teacher's competences, agency, intercultural dialogue in the process of studying mathematics, cultural values in education.

Постановка проблеми. XXI століття характеризується формуванням нового соціально-культурного середовища, однією із основних особливостей якого $€$ так звана агентність, що передбачає активну участь представників усіх верств суспільства у створенні інформаційного контенту, продукуванні в його межах можливих способів реагування на ключові виклики сучасності, пов'язані із загостренням соціальних, технологічних, економічних проблем сучасності.

Сьогодні освіта, як і всі інші сучасні галузі людської діяльності, стикається із феноменом бурхливого розвитку агентності іiї суб'єктів і користувачів, яку слід розуміти як здатність ставати активною, мислячою, автономною, креативною, спроможною на інновації особистістю у процесі іiі здобуття. Розвиток нових інформаційних технологій уможливив такі прояви агентності, як перехід від ситуації споживання й відтворення знань у системі освіти до безпосередньої участі суб'єктів навчання у продукуванні знань й ухваленні на їх основі вмотивованих і обгрунтованих рішень.

Варто зауважити, що прискорення процесів глобалізації й технологічного розвитку призводить не лише до появи нових можливостей щодо підсилення явища агентності в галузі освіти - персоналізації навчального середовища, яке сприяє ефективнішому формуванню міцної бази необхідних в епоху глобальної диджиталізації знань, але й до виникнення нових форм освітньої й самоосвітньої діяльності, що суттево змінюють взаємини між ії суб' єктами, призводячи як до формування й поповнення системи знань, так і до розвитку нових соціальних компетенцій, важливою складовою яких $є$ полікультурна компетентність.

Аналіз наукових досліджень та публікацій. Питанням агентності освіти й формуванню в ії контексті полікультурної компетентності суб'єктів освітнього процесу присвячені багаточисельні публікації вітчизняних і світових учених, політиків, діячів культури й представників бізнесу, які є візіонерами, що визначають перспективні цивілізаційні напрями розвитку. Програмний документ Ради Свропи «Компетентності для культури демократії. Живемо разом як рівноправні громадяни в культурно багатоманітному демократичному суспільстві» [5] подає нову концептуальну модель компетентностей, які визначають здатність людини до продуктивного життя й ефективної взаємодії $з$ іншими людьми в багатоманітних суспільствах, зокрема й мережевих. Нові рамки компетентностей для виховання культури й толерантності, окреслені цим документом, знайшли своє відображення і в навчальних програмах з математики для 33СО [3].
Так, у пояснювальній записці навчальної програми 3 математики для 5 - 9 класів стверджується, що «навчання математики має зробити певний внесок у формування ключових компетентностей» здобувачів освіти. У дев'ятому пункті переліку ключових компетентностей та їх компонентів йдеться про обізнаність та самовираження в галузі культури, що передбачає вміння здійснювати необхідні розрахунки для встановлення пропорцій, відтворення перспективи, створення об'ємно-просторових композицій тощо, а також усвідомлення взаємозв'язку математики $\boldsymbol{i}$ культури на прикладах з архітектури, живопису, музики тощи.

Концептуальна рамка навчання 2030, викладена в проєкті «Майбутнє освіти та вмінь. Освіта 2030» Організації економічного співробітництва та розвитку (Organisation for Economic Co-operation and Development (OECD)) [8], передбачає виховання в процесі навчання «відчуття відповідальності та готовність брати участь у формуванні світу, змінювати людей, події та обставини на краще. Поняття агентності у цьому сенсі вимагає здатності формулювати далекосяжну мету та визначати кроки задля іiі досягнення». Усвідомлення агентності сучасної освіти $\epsilon$ важливою вимогою часу, оскільки агентність як суттєва особливість суб'єкта дії, зокрема й освітньої, має на меті розуміння ним значущості здобутих знань для продуктивної інтеграції в глобалізоване соціальне середовище сучасного світу, яке характеризується багатокультурним різноманіттям.

Ключові напрями впровадження принципів розуміння й толерантного ставлення до полікультурності глобалізованого світу викладені в програмному документі ЮНЕСКО «Загальна декларація щодо культурного різноманіття» (UNESCO Universal Declaration on Cultural Diversity) [9]; загальноєвропейські дефініції стандартів культурного різноманіття й ключових понять, пов'язаних із ним (наприклад, «глобалізація», «мультикультуралізм», «полікультурне різноманіття» тощо), представлено в документах Асоціації бібліотек коледжів і дослідницьких установ (The Association of College \& Research Libraries (ACRL)) [7] - європейського підрозділу асоціації наукових бібліотек США, на онлайн-ресурсах відомих бізнес-порталів (зокрема Graziadio Business Review у статті «Як полікультурна компетентність забезпечує успіх глобальних віртуальних співтовариств» (How Intercultural Competence Drives Success in Global Virtual Teams)) [6].

Проблеми формування полікультурної компетентності в сучасному освітньому середовищі висвітлені в роботах Н. Р. Азізової [1], А. М. Бекбулатової [2], I. А. Новікової [4] та ін.

Мета статті - проаналізувати перший етап проєкта «Культурні коди математики», що спрямований на розробку науково-методичних засад інноваційного розвитку процесу підвищення кваліфікації вчителів математики в регіональній системі післядипломної педагогічної освіти в напрямі формування й розвитку їх полікультурної компетентності.

Зважаючи на мету, основним завданням статті $\epsilon$ висвітлення результатів анкетування вчителів математики Рівненської області, спрямованого на 3'ясування розуміння ними сутності сучасних тенденцій та актуальних принципів професійного розвитку в контексті модернізації неперервної педагогічної освіти. 
Виклад основного матеріалу. Створення проєкта «Культурні коди математики» зумовлене потребою в розробці науково-методичних засад інноваційного розвитку процесу підвищення кваліфікації вчителів математики в регіональній системі післядипломної педагогічної освіти і спрямоване на побудову моделі формування однієї зі складових системи професійних компетентностей - полікультурної компетентності педагогів в умовах курсової підготовки та в міжатестаційний період. Актуальність проєкта пов'язана з тим, що педагогічні технології, які використовуються вчителями математики Рівненської області, недостатньо сприяють формуванню полікультурної компетентності учнів 33СО, тоді як саме полікультурна компетентність $є$ дуже важливою складовою продуктивної життєдіяльності особистості в сучасному глобалізованому світі, подекуди сповненому соціальних, економічних і міжетнічних конфліктів.

Аби з'ясувати ступінь готовності вчителів математики до впровадження технологій формування й розвитку полікультурної компетентності, яка може стати чинником гармонізації внутрішнього світу здобувачів освіти із глобалізованим реальним і віртуальним середовищем буття, сповненим культурного різноманіття, нами було проведено анкетування слухачів курсів підвищення кваліфікації.

Анкета, зокрема, вміщувала такі запитання:

1. Оберіть три найактуальніші, на Вашу думку, тренди професійного розвитку педагогів в умовах інноваційного освітнього середовища післядипломної освіти:

1.1. Формування професійних компетентностей.

1.2. STEAM-освіта (Science, Technology, Engineering, Art, Mathematic).

1.3. Практико-орієнтоване навчання, спрямоване на конкретні результати.

1.4. Персоналізація освіти, проєктний підхід до підвищення кваліфікації.
1.5. Розвиток дослідницького підходу до самоосвіти й саморозвитку педагога.

1.6. Зміна ролі викладача закладу післядипломної освіти й здобувача неперервної післядипломної педагогічної освіти.

2. Чи вважаєте Ви полікультурну компетентність педагога однією зі складових його професійної компетентності?

2.1. Так.

2.2. Hi.

2.3. Не знаю, що таке полікультурна компетентність педагога.

3. Чи вважасте Ви правильним рішенням оновлення програм післядипломної педагогічної освіти відповідно до актуальних трендів європейських $i$ світових освітніх стандартів щцодо розуміння ідей та культурних цінностей різних соціальних груп $i$ цивілізацій?

3.1. Так.

3.2. Hi.

3.3. Важко сказати.

4. Оберіть три, на Вашу думку, найбільш незрозумілих щцодо їх практичної реалізації складових професійної компетентності вчителя математики:

4.1. Методична компетентність.

4.2. Предметна компетентність.

4.3. Психолого-педагогічна компетентність.

4.4. Полікультурна компетентність.

4.5. Аксіологічна компетентність.

4.6. Соціально-психологічна компетентність.

Попереднє опрацювання результатів анкетування засвідчило такі основні тренди, як надання переваги формуванню професійних компетентностей у процесі підвищення кваліфікації, посилення запиту на практико-орієнтоване навчання, а також підвищення інтересу до впровадження методів STEAM-освіти (див. рис. 1).

\section{Актуальні тренди професійної освіти педагогів}

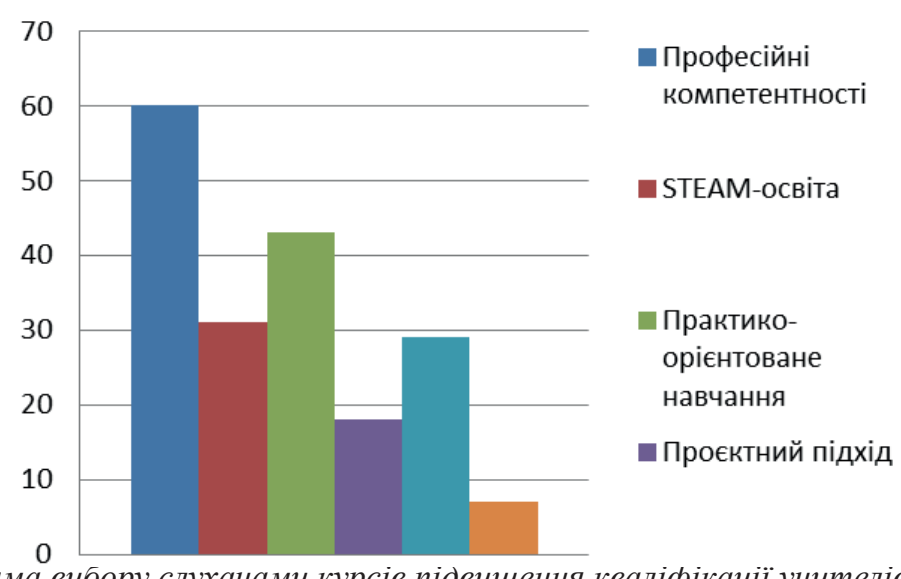

Рис. 1. Діаграма виоору слухачами курсів підвищення кваліфікації учителів математики актуальних трендів професійної освіти

Дані діаграми засвідчують, що на сьогодні вчителі поки не готові до зміни ролі викладача закладу післядипломної освіти й слухача курсів підвищення кваліфікації, яка передбачає перехід до активних методів навчання (наприклад, проєктного i дослідницького підходу). Саме тому проєкт «Культурні коди математики», який забезпечує діяльнісний підхід до вдосконалення якості та ефективності курсової підготовки й самоосвіти вчителів математики, є актуальним і відповідає інноваційним трендам розвитку післядипломної педагогічної освіти.

Важливо зазначити, що майже всі опитані (90 \%) уважають полікультурну компетентність педагога однією зі складових його професійної компетентності, але при цьому мають труднощі із розумінням iii сутності та практичного формування й розвитку (див. рис. 2). 


\section{Полікультурність - складова професійної компетентності}

Так

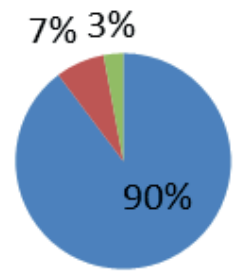

Рис. 2. Діаграма вибору полікультурності як складової професійної компетентності педагога

Аналіз відповідей щодо проблем із практичною реалізацією складових професійної компетентності сучасного вчителя математики засвідчив, що з найбільшими труднощами педагоги стикаються при спробах упровадження технологій розвитку ціннісних орієнтирів сучасних школярів, їх соціальної адаптації й упровадження основ полікультурної освіти.

Таким чином, попередні результати першого етапу впровадження проєкта «Культурні коди математики» засвідчили його актуальність щодо формування й розвитку рефлексивно-аналітичних умінь педагогів, пов'язаних із критичним осмисленням комплексу цілей і завдань сучасної освіти та труднощів його практичної реалізації.

Висновки. Отже, завдяки реалізації першого етапу регіонального проєкта «Культурні коди математики», спрямованого на з'ясування сутності сучасних тенденцій та актуальних принципів професійного розвитку вчителів математики в контексті модернізації неперервної педагогічної освіти, було виявлено основні проблеми, пов'язані з підвищенням ефективності післядипломної педагогічної освіти щодо формування полікультурної компетентності - одного 3 провідних трендів сучасної освіти. Аналіз даних, отриманих у ході першого етапу опитування, засвідчує необхідність обгрунтування критеріїв та показників розвитку полікультурної компетентності педагогів в умовах інноваційного освітнього середовища післядипломної освіти.

Перспективи подалыших досліджень в означеному напрямі вбачаємо у вивченні практичних цілей і завдань полікультурної освіти вчителів математики, спрямованої на розуміння важливості формування у здобувачів освіти системи як національних, так і загальнокультурних цінностей, розвиток умінь проєктувати способи педагогічних впливів, що грунтуються на результативному управлінні процесом учіння, здатному забезпечити адекватну відповідь на реальні виклики й проблеми світу, сповненого культурного різноманіття.

\section{СПИСОК ВИКОРИСТАНОЇ ЛІТЕРАТУРИ}

1. Азизова Н. Р. Вопросы поликультурной компетентности работников образования в курсах повышения квалификации педагогов / Н. Р. Азизова // Социальное воспитание. - 2017. - № 1 (9). - C. 4. URL: https://elibrary.ru/item.asp?id=27725319 (дата звернення: 12.12.2019).
2. Бекбулатова А. М. Модель поликультурной компетентности педагога в образовательной среде / А. М. Бекбулатова // Концепт : научно-методический электронный журнал. - 2017. - Т. 39. - С. 2026-2030. URL: http://e-koncept.ru/2017/970732.htm (дата звернення: 12.12.2019).

3. Навчальні програми 5-9 класи. Наскрізні змістові лінії // Сайт Інституту модернізації змісту освіти. URL: https://imzo.gov.ua/osvita/ zagalno-serednya-osvita-2/navchalni-prohramy-59-klasy-naskrizni-zmistovi-liniji/ (дата звернення: 15.12.2019).

4. Новикова И. А. Формирование и развитие поликультурной компетентности педагогических работников в постдипломном образовании. URL: https://research-journal.org/pedagogy/formirovanie-irazvitie-polikulturnoj-kompetentnosti-pedagogicheskixrabotnikov-v-postdiplomnom-obrazovanii/ (дата звернення: 11.12.2019).

5. Competences for democratic culture - Living together as equals in culturally diverse democratic societies. URL: https://book.coe.int/en/human-rightsdemocratic-citizenship-and-interculturalism/7736competencies-for-democratic-culture-living-together-asequals-in-culturally-diverse-democratic-societies.html (дата звернення: 10.12.2019).

6. Graziadio Business Review. URL: https://gbr. pepperdine.edu/2010/08/how-intercultural-competencedrives-success-in-global-virtual-teams/ (дата звернення: 14.12.2019).

7. The Association of College \& Research Libraries (ACRL). URL: http://www.ala.org/acrl/standards (дата звернення: 16.12.2019).

8. THE FUTURE OF EDUCATION AND SKILLS. Education 2030. Organisation for Economic Cooperation and Development (OECD). URL: https:// www.oecd.org/education/2030/E2030\%20Position $\% 20$ Paper\%20.pdf (дата звернення: 05.04.2018) (дата звернення: 05.12.2019).

9. UNESCO Universal Declaration on Cultural Diversity. URL: http://portal.unesco.org/en/ev.php-ID= 13179\&URL_DO=DO_TOPIC\&URL_SECTION=201. html (дата звернення: $\overline{1} 3.12 .2019$ ).

Дата надходження до редакиіï: 20.12.2019 р. 